\title{
Introduction
}

\section{SWIM THE LONE STAR STATE}

It's the middle of July. Bank marquees and car thermometers clock another $104^{\circ}$ day. Air conditioners moan. Brooklyn transplants weep. Everyone sweats. Across Texas, drivers gingerly pull seat belts across our laps, careful to avoid meeting skin to scorching metal. We settle Topo Chicos into cup holders, crank as much cold air as our car engines can summon, and point our vehicles toward the only destination that holds relief: one of Texas's natural swimming holes.

As quintessential to Texas as Lone Star Beer, barbecue, and Willie Nelson's Fourth of July picnic, swimming holes are vital to surviving the region's endless, sweltering summers. Ordinary concrete pools don't compare to the transcendent calm of clear springwater, old-growth trees, and wide-open skies; they can't offer the sense of adventure that comes from piling friends, family, and picnic essentials in the car for a road trip, short or long.

But how do you choose which of the dozens of possible oases to visit? Pedernales Falls? Blue Hole? Garner State Park? Amistad Reservoir? Boykin Springs? The state of Texas is home to hundreds of lakes, rivers, and spring-fed holes, each one boasting its own unique natural magic. Otherworldly grottoes and waterfalls, hidden canyons, and an endless variety of animal 
and plant life distinguish each sweet spot from the next one on the map. Where do you begin?

This guide is here to help. The Swimming Holes of Texas is a curated list of over one hundred of the best swim spots across the state. From as far north as Quanah to as far west as Balmorhea, these are top recommended places to jump into natural water and cool off, based on empirical research conducted by two authors armed with towels, sunscreen, and the mission to drive across Texas tracking down every promising piece of water on the map. The guiding criteria were simple: Is this water we want to swim in? Are there reasonable amenities? Do we feel safe and relaxed? And, most important, would we want to come here again?

Preserved, protected, and sources of pride, the swimming holes of Texas and the parks that house them are among the Lone Star State's most celebrated pleasures. Keep this guide in your bag or backseat all summer long as inspiration for spontaneous road trips and weekend adventures. With this book in one hand and a bottle of sunblock in the other, you'll be ready to dive into everything a Texas summer has to offer.

\section{Planneng Your Trip}

This guide is organized around six regions: North, East, Central, Austin and surrounding area, South, and West. We define North as the area north of Georgetown, including the Dallas-Fort Worth metroplex and the Panhandle. East includes the Pineywoods and Big Thicket regions. South encompasses locales south of Interstate 10 and east of I-35. West covers anything that lies west of Utopia and south of I-10.

Basic information regarding operating hours, fees, amenities, and park rules is included. For comprehensive and up-tothe-minute information, call ahead to your destination or visit its website. 